\title{
The Cultural Enlightenment of D. H. Lawrence's Ecological Consciousness on China's Ecological Civilization
}

\author{
Xiuzhi Zhang ${ }^{1, a}$ and Hongmei Yang ${ }^{1, b}$ \\ ${ }^{1,2}$ School of Foreign Studies, Xi'an University of Arts and Sciences, Xi'an 710065, China

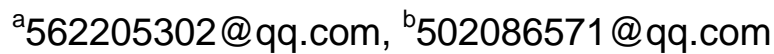

\begin{abstract}
Keywords: D.H.Lawrence; Ecological consciousness; Ecological civilization; Cultural enlightenment
\end{abstract}

\begin{abstract}
Starting from the perspective of human tragedy brought about by the unplanned industrial development, D. H. Lawrence explores the distorted relationship between human and nature, exposes the tragic problems of the western society caused by the British capitalist industrial civilization. In addition, he also elaborates his worries about the living environment of mankind. Now, China, as a developing country, should learn the lessons already taught by the previous experience of the west so that the problems of ecological alienation can be solved in the bud. Therefore, to some extent, Lawrence's ecological consciousness represented in his works provides some cultural enlightenment for our contemporary ecological development.

Ecological civilization was one of the western postmodern social cultures in the late $20^{\text {th }}$ century.The writers in that stage concerned about man's mind, explored the relationship between man and nature, man and man, man and society and even man and himself and what they wanted to express was "to return to nature and to love nature". In their mind, the pure and quiet nature could purify man's soul, let people forget the earthly troubles. In the embrace of nature, man could draw nutrients, feel and appreciate the charms of nature. Therefore, man began to understand and learn to respect nature, at the same time, to explore the relationship between human and the earth. Besides, man must realize if he wants to survive, he must love nature and protect nature.
\end{abstract}

\section{H. Lawrence's Ecological Consciousness}

D.H.Lawrence is a British writer with a strong sense of social responsibility and humanitarianism. From the critical point of view, he pays attention to people's living environment, concerns for human's survival, and tries every means to find a solution to get people out of social troubles. Nearly all his works express his love for nature, his ideal life in the wild nature and his spiritual enjoyment in the material world. He hopes that human should have a close contact with nature.

The Influence of Nature on Man. Lawrence's work The Rainbow describes the life of three generations of the Brangwen family on the Marsh Farm, showing us the green grass, trees, fields and the Brangwen's simple harmonious life complying with the natural rhythm and pulse of life before the industrial revolution. This kind of life reflects the natural harmony between man's life and nature. Besides, Lawrence emphasizes the spiritual vitality of nature. He thinks the mysterious power from nature can awaken man's natural vitality, make man rebirth. In his heart, "man is no longer a conqueror of nature, but a natural child."[1] So nature is closely related to man. Nature can purify people's souls, make people delighted, even provide comforts to people. In Women in Love, Lawrence depicts one scene that Birkin is lying on the green grass in the deep valley, the soft grass is like the mother's arms that can comfort him. In this beautiful scenery, he is completely intoxicated and he gets energy from the nature. Here he becomes a child of nature.

In Lady Chatterley's Lover, Lawrence shapes the typical lovers being naturally reintegrated. In this work, the author depicts Connie and Mellors' sexual love in nature. Here, the author symbolizes sex as beauty, hope and lively life. The completeness and compliment of love are completely revealed. In nature, "the so-called civilized persons who have been contaminated by industrial civilization, still having pure and natural emotions" [2]come back to life. The combination of nature and people's inbred original energy demonstrates their ideal harmonious unity of both body and 
soul. Connie gains the warmth and passions that she has never experienced. Therefore, in Lawrence's mind, the earth not only provides the material resources for the human existence, but also gives the human spiritual enjoyment. "Thus Humans should step over the barrier between human and nature to be closer to nature psychologically. This is the basic way of calling for natural spirit."'[3] Man should return to nature and live harmoniously with nature. The beauty of nature can bring new life to man and even can purify man's soul and also offer comforts to man.

Loving Nature and Longing for the Harmonious Relationship Between Man and Nature, Man and Man. Man and nature are inextricably linked and man's relationship with nature is constantly evolving. however, the contemporary world has transformed man's interaction with nature.[4] With the deepening of industrialization, the quietness and peace of beautiful nature have been destroyed since the industrial civilization, so the confrontation between man and nature has been formed. Having observed the abuse of nature, Lawrence exposes the problems brought about by the industrial civilization and foretells that this kind of development will be disastrous to mankind. Besides, the social turbulent situations in the early twentieth Century makes Lawrence fully realize the depressed nature of man, the individual self-split and the deformed relationship between man and nature. In some of Lawrence's works such as Sons and Lovers, The Shadow in the Rose Garden and Odor of Chrysanthemums, Lawrence finds the full expression in confrontation of man and even the inhospitality between husband and wife. He hopes that man should be kind to companions and they should live a harmonious life. Therefore, from the tragic perspective of human civilization, Lawrence explores the relationship between human life and nature, at the same time expresses man's longing for life in the Garden of Eden. So Lawrence's works suggest that people should undertake a careful reassessment of all causes that lead to the great changes of the relationship between man and nature, that they should reconsider their attitude towards nature. "Man should not dominate nature because he is one part of it. He must comply with natural principles and keep balance with nature."[5] In one word, Lawrence thinks that man should love and respect nature and that man and nature should coexist peacefully.

\section{The Cultural Enlightenment of D. H. Laurence's Ecological Consciousness on China's Ecological Civilization}

The human society is progressing constantly. Only by handling the relationship between man and nature in the correct way can we live harmoniously with nature. In addition, the relationship between man and man, man and society can reach to a harmonious level. Modern technology known as the material progress and the improvement of human power rids people from hunger and poverty. However, to some extent, technology is a threat to human self- perfection.[6] The modern society (the industrial society) excels the agricultural one. Since the $20^{\text {th }}$ century, the industrial society has developed rapidly, and people's mind has also changed. So people focus their attention on the material things and they try to extract more things form nature that are beyond the bearing of nature. So the relationship between man and nature becomes to conquer and to be conquered, and even the relationship between man and man has reached to a crisis point.

Now, people have already been aware of the social and ecological crises brought about by the development of modern technology. If some effective measures cannot be taken to abate the crises and the current situation becomes no better, it will inevitably result in people's indifference to these problems. Therefore, in the rapid development of the society providing rich material for us to enjoy, we explore the ecological ideas represented in D.H.Lawrence's works so as to arouse people's vigilance and attention to the natural, human and social problems. Thus Lawrence's ecological consciousness can be used for reference for the ecological development of our country.

Building a Civilized Ecological Consciousness. To some extent, D.H.Lawrence's ecological consciousness coincides with the cultural ecological ideas of ancient Chinese. In ancient times, we Chinese advocated the harmony between man and nature, identity of man and materials. This really means the integrity of man and nature. The Chinese ancient philosophical thought was based on the outlooks of a mixture of subject and object, and they regarded the world as an organic, flexible, humane natural environment, and they pursued the harmony between human and nature. So social 
development should not hurt the relationship of man and nature, for man's means of existence is wrung from nature. All these coincide with Lawrence's ecological thought. However, with the rapid development of the modern society, we are confronted with severe ecological crisis. The industrialization has brought smog, acid rain, sandstorm, water shortages, air pollution, depletion of resources, shortage of energy, deforestation and malignant expansion of deserts, which turns to be a serious threat to the human survival and social development. Finally the sudden surge of the population and unplanned exploitation of natural resources lead to the confrontation of man and nature as well as social problems. All these have brought lots of problems to man's existence. This is the tragic event foretold by D.H.Lawrence. Therefore, our party's 19th conference pointed out: we should speed up the reform of ecological civilization system and make China a beautiful country. In this case, we should try to find a way to the ecological crisis we are facing now. The most importance lies in building up our ecological thought and making us realize that we should take a correct attitude towards the earth which we depend on living. Eco-civilization is a new form of human society. We should advocate eco-civilization and take the human society into consideration from the perspective of sustainable development. In addition, we should pay attention to the problems Lawrence exposed in his works. Only by changing our thinking to our relationship and nature can we solve the problems.

Establishing Ecological Civilization Based on Education. Lawrence is a great ecological prophet. His criticism to industrial civilization makes us realize that we should establish the cultural and ecological outlooks. The rapid development of society brings in enormous material enjoyment to us, at the same time a lot of problems to nature and man. Most of men are lost in the material society and they ignore the relationship between human and ecological nature. Lawrence hopes that the development of the society should comply with nature. Now, it is necessary for us to have a further interpretation of Lawrence's works, especially Lawrence's ecological ideas to arouse the whole world to pay more attention to some social ecological problems. We people must try to infiltrate the ecological thought into the children's education and constantly strengthen ecological learning. We should take the ecology as a compulsory course for students ranging from Chinese primary schools to high schools to learn, and let the students get to know more about nature and love nature and protect nature. Besides, we should take the ecological moral education as a lifelong education for all the students and the whole citizens. Only in this way can we value ecological protection very highly.

Constructing an Ecological Society Full of Human Love and Harmony. Constructing an ecological and harmonious society lies in forming a harmonious family and a harmonious family is based on the good relationship between man and woman.[7] Lawrence stresses that people should set up an integral relation among people, especially among family members. The ecological society is the one in which people coexist harmoniously, including the harmony between man and nature, man and man, man and society. Society is made up of people, and people should live peacefully and are kind to each other. Only by establishing the harmonious society will we avoid the problems of human alienation and human spiritual split-up revealed by Lawrence.

Jintao $\mathrm{Hu}$ pointed out:"The fact shows that the poor relationship between man and nature often affects the relationship between man and man, man and society."[8] So improving this deformed relationship becomes a main focus for people at present. To improve the relationship between man and nature, we should set up a harmonious society in which all men care for each other, help each other and live harmoniously with each other. We should learn the lessons already taught by the experience of our forefathers' and control ecological alienation in the early stage. Thus constructing an ecological society is all Chinese' strong wishes.

\section{Conclusion}

Lawrence is a writer with modernist features. His works embody his understanding of the deformed relationship between man and nature, man and man as well as man and society. His concern for human, his love for nature and his ideas of returning to nature is in accord with our party's requirement. What Lawrence proposed is the important reference for our cultural ecological 
construction. We should have a deeper understanding and thinking of human ecological problems now as to promote the construction of ecological civilization.

China is a big country developing really very fast, so we should build a harmonious society and try to find some proper solutions to the social problems we are facing. Only by doing this can we avoid the natural and social crises.

\section{References}

[1] R.C. Zhao: An Interpretation of Women in Love from the Perspective of Eco-feminism (A Special Study of Feminist Literature,2008),p.95.(in Chinese)

[2] Y.T. ZHOU: Eco-feminism Analysis of D.H.Lawrence's Lady Chatterley's Lover (M.s.Xi'an International Studies University 2017),p.52

[3] Y.T. Ren: The Reconciliation Between Man and Nature: An Ecocritical Study of D.H.Lawrence's The Rainbow (M.S. Dalian University of Technology,2015),p.iii.

[4] http://www.studymode.com/essays/Nature-v-s-Nurture-899167. html

[5] J.Y. Xu: An Interpretation of Lawrence's Women in Love from the perspective of ecological ethics (Journal of Chifeng University ), Vol.37 (2016)No.4,p.165(in Chinese)

[6] Z.H. Hu: Research on the Western Eco-criticism (China Social Science Press, 2006) (in Chinese)

[7]Y.Fu,Y.Wen: An Brief Analysis of the Feminist View in The Rainbow Literatures, Vol.25 (2011)No.3,p.20 (in Chinese)

[8] http://cpc.people.com.cn 